Antimicrob Chemother 1995;34:529-544.

86. Tetteroo GW, Wagenvoort JH, Bruining HA. Bacteriology of selective decontamination: efficacy and rebound colonization. J Antimicrob Chemother 1994;34:139-148.

87. Kaufhold A, Behrendt W, Kräuss T, van Saene H. Selective decontamination of the digestive tract and methicillin-resistant Staphylococcus aureus. Lancet 1992;339:1411-1412.

88. Archer GL, Armstrong BC. Alteration of staphylococcal flora in cardiac surgery patients receiving antibiotic prophylaxis. J Infect Dis 1983;147:642-649.

89. Beard-Pegler MA, Stubbs E, Vickery AM. Observations on the resistance to drying of staphylococcal strains. J Med Microbiol 1988;26:251255.

90. Frénay HME, Theelen JPG, Schouls LM, Vandenbroucke-Grauls CMJE, Verhoef J, van Leeuwen WJ, et al. Discrimination of epidemic and non epidemic methicillin-resistant Staphylococcus aureus strains on the basis of protein A polymorphism. J Clin Microbiol 1994;32:846-847.

91. Roberts JIS, Gaston MA. Protein A and coagulase expression in epidemic and non-epidemic Staphylococcus aureus. J Clin Pathol 1987;40:837-840.

92. van Wamel WJB, Fluit AC, Wadström T, van Dijk H, Verhoef J, Vandenbroucke-Grauls CMJE. Phenotypic characterization of epidemic versus sporadic strains of methicillin-resistant Staphylococcus aureus. J Clin Microbiol 1995;33:1769-1774.

93. Bisognano C, Vaudaux PE, Lew DP, Ng EYW, Hooper DC. Increased expression of fibronectin-binding proteins by fluoroquinolone-resistant Staphylococcus aureus exposed to subinhibitory levels of ciprofloxacin.
Antimicrob Agents Chemother 1997;41:906-913

94. Jepsen OB. The demise of the 'old' methicillin-resistant Staphylococcus aureus. J Hosp Infect 1986;7(suppl A):13-17.

95. Witte W, Braulke C, Heuck D, Cuny C. Analysis of nosocomial outbreaks with multiply and methicillin-resistant Staphylococcus aureus (MRSA) in Germany: implications for hospital hygiene. Infection 1994;2(suppl 2):S128-S134.

96. van Eldere J, Borremans A, Schuermans A, Thelissen MJ. Methicillin resistant Staphylococcus aureus in the university hospitals Leuven. Study of their origin and spread and of the effect of measures to reduce their presence. Bulletin d'Information Hygiène Hospitalière (Belgium) 1995; 17:46-47.

97. Aubry-Damon H, Legrand P, Brun-Buisson C, Astier A, Soussy C-J, Leclercq R. Reemergence of gentamicin-susceptible strains of methicillin-resistant Staphylococcus aureus: roles of an infection control program and changes in aminoglycoside use. Clin Infect Dis 1997;25:647653.

98. Lemaitre N, Sougakoff W, Masmoudi A, Fievet M-H, Bismuth R, Jarlier V. Characterization of gentamicin-susceptible strains of methicillin-resistant Staphylococcus aureus involved in nosocomial spread. J Clin Microbiol 1998;36:81-85.

99. Harstein AI. Improved understanding and control of nosocomial methicillin-resistant Staphylococcus aureus: are we overdoing it? Infect Control Hosp Epidemiol 1995;16:257-259.

100. Dunkle LM, Naqvi SH, McCallum R, Lofgren JP. Eradication of epidemic methicillin-gentamicin-resistant Staphylococcus aureus in an intensive care nursery. Am J Med 1981;70:455-458.

\title{
Hepatitis GB Virus Infection Among Renal Transplant Patients
}

\section{Gina Pugliese, RN, MS Martin S. Favero, $\mathrm{PhD}$}

The etiology of liver disease remains unknown in approximately $4 \%$ to $23 \%$ of dialysis patients and $10 \%$ to $16 \%$ of renal transplant recipients. A search for other causative agents of liver disease led to the discovery of the GB group of viruses. Investigators from the New England Medical Center in Boston studied the association between the presence of GB virus C (GBV-C) infection, known risk factors for parenterally transmit ted infections, and history or laboratory evidence of liver disease among end-stage renal disease (ESRD) patients referred for renal transplantation to the New England Organ Bank, Massachusetts.

Stored sera from patients on the renal transplantation waiting list between Novem- ber 1986 and June 1990 were tested for antibody to hepatitis $\mathrm{C}$ virus (HCV). Sera were available in 1,544 (48\%) of 3,243 patients, and anti-HCV was detected by enzyme-linked immunosorbent assay in 287 (19\%). All 287 anti-HCV-positive patients formed the antiHCV positive cohort, and 286 randomly selected anti-HCV-negative patients formed the anti-HCV-negative cohort (573 patients overall). Additional sera were available for GBV-C RNA testing in 465 of 573 (81\%) patients, and GBV-C RNA was detected by reverse transcriptase polymerase chain reaction in 146. The overall extrapolated prevalence of serum GBV-C RNA was $29 \%$. The prevalence of serum GBV-C RNA among anti-HCV-positive patients (35\%) was not significantly different from that among anti-HCV negative patients (29\%; $P=.22$ ). In a step-wise multivariate regression analysis, a younger age (odds ratio
[OR] 0.98 per year of age, $P=.03)$ and history of blood transfusions (OR, 3.89, $P=.03$ ) were associated with an increased $\mathrm{OR}$ for serum GBV-C RNA, whereas diabetes mellitus was associated with a decreased OR for GBV-C RNA (OR, 0.47, $P=.01$ ). Anti-HCV was not a predictor of serum GBV-C RNA (OR 1.07, $P=.77$ )

The results of this study support the conclusion that GBV-C is a parenterally transmitted virus and shed light on the modes of transmission of GBV-C among ESRD patients. However, the association with liver disease remains to be established.

FROM: Murthy BV, Muerhoff AS, Desai SM, Natov SN, Bouthot BA, Ruthazer $\mathrm{R}$, et al. Predictors of GBV-C infection among patients referred for renal transplantation. Kidney Int 1998;53:1769-1774.

\section{Contamination of Sterile Biopsy Forceps in Disinfected Endoscopes}

Investigators from the Virginia Mason Medical Center, Seattle, Washington, studied contamination risk from endoscope biopsy forceps after high-level disinfection.

All endoscopes had been processed previously and stored for 10 or more hours. Sterile biopsy forceps were inserted and retrieved, followed by vortexing the tips in $15 \mathrm{~mL}$ of soy broth; bacterial growth was minimal. Soy broth was flushed through endoscopes and collected. Biopsy forceps underwent a total of 24 anaerobic and 75 aerobic cultures. Microbiological growth occurred on 17 plates: 7 from gastroscopes,
5 from colonoscopes, and 5 from duodenoscopes. Fifteen plates grew staphylococci for a total of 21 colonies, 1 plate grew 1 colony of Propionibacterium, 2 plates grew diphtheroids for a total of 4 colonies, and 1 plate grew a single colony of Lactobacillus. Cultures from soy broth flushed through the various endoscopes grew on 5 plates: 3 from gastroscopes and 2 from duodenoscopes grew a total of 8 colonies of staphylococci.

The authors concluded that, with proper cleaning technique, a 20-minute soak in $2 \%$ glutaraldehyde is effective in dis- infecting endoscopes. Although current procedures for endoscope disinfection remain imperfect, they found that, in this clinical setting, infection by pathogenic gastrointestinal flora is unlikely when using sterile biopsy forceps.

FROM: Lee RM, Kozarek RA, Sumida SE, Raltz SL. Risk of contamination of sterile biopsy forceps in disinfected endoscopes. Gastrointest Endosc 1998;47 (5):377-381. 